\title{
Diversity and Biomass of Terrestrial Small Mammals at A Malaysian Primary Rainforest (Segari Melintang Forest Reserve, Peninsular Malaysia)
}

\author{
Nadine Brigitte Ruppert ${ }^{*^{*}}$, Asyraf Mansor ${ }^{1}$, Shahrual MS Anuar ${ }^{1}$
}

${ }^{1}$ School of Biological Sciences, Universiti Sains Malaysia

\begin{abstract}
Despite their importance for the rain forest ecosystem, it is still not much known about the community composition of small frugivorous mammals in West-Malaysian forests. Therefore, we conducted a mark and recapture study in four $100 \mathrm{~m}$ x $100 \mathrm{~m}$ sized plots in a lowland Dipterocarp forest of Peninsular Malaysia for 4000 trap nights. Plots hosted either Dipterocarp forest or alluvial freshwater swamp vegetation. We assumed that small mammal assemblages varied between these two vegetation types. In total 249 different individuals of 14 species (9 genera) were caught, comprising rodents and treeshrews. The most abundant species was the common treeshrew (Tupaia glis, 25.8 individuals $\mathrm{ha}^{-1}$ ). In second and third place were the plantain squirrel (Callosciurus notatus, 10.25 individuals $\mathrm{ha}^{-1}$ ) and the grey tree rat (Lenothrix canus, 10.0 individuals ha ${ }^{-1}$ ), respectively. These three species accounted for $77.8 \%$ of the total small mammal's biomass per hectare. Sex-ratio of treeshrews and squirrel species was found at 1:1, whereas Muridae showed male-biased sex ratios. Shannon-diversity indices ( $\left.\mathrm{H}^{\prime}\right)$ of all trapping plots ranged at a mediocre level. Plot comparison (Bray-Curtis indices) showed that plots with similar vegetation types were not more similar in their small mammals community structure. Other factors, such as dis tance to the forest edge and joining oil palm plantations seemed to influence species abundances. Small mammals belong to the less studied species in local rain forests, thus studying their ecology is vital to act towards general conservational issues.
\end{abstract}

Keywords: mark and recapture study, nonflying mammals, small mammal abundance

\section{INTRODUCTION}

The tropical forests of the Malay Peninsula host 205 known mammal species of 32 families (11 orders) [1]. Amongst them is the guild of small (weight less than $1 \mathrm{~kg}$ ), non-flying, terrestrial, frugivorous mammals. They consist of various taxonomic groups and represent a vital component of this ecosystem. For example, they act as pollinators [2-4], fruit predators and seed dispersers [5-9] or valuable energy source when becoming a prey for larger carnivores [10].

Although, small mammals occur in complex communities with very high species richness and considerable impact on the Malaysian rainforest ecosystem, they have not received much public or conservational attention, yet [11]. Especially the small mammals of the Peninsular are only little addressed in literature [12-17]. In fact, the least known mammals in the re-

\section{*Corresponding author:}

Nadine Brigitte Ruppert

School of Biological Sciences, Universiti Sains Malaysia

Email: n.ruppert@usm.my gion include squirrels, treeshrews, rats, mice, and civets [18]. This might be due to their mostly cryptic appearance and behaviour. Many of them are quite small, night active or forage high up in the canopy, hide in trees and burrows, or are rather trap shy.

For this study we put our focus on frugivorous ground dwellers and tree climbers up to medium forest levels (app. $5 \mathrm{~m}$ above ground). However, a wider range of small mammals, i.e. several squirrel or Muridae species, are only found higher up in the canopy [19].

The most abundant group of small non-flying mammals comprises rats and mice (order Rodentia, family Muridae) that are mostly night active and very diverse. They can be found on the ground where they forage and rest in burrows, at medium forest levels, where they climb trees and nest in tree holes, as well as high up in the canopy. It is still very little known about this highly diverse family in South-East Asian primary forest systems, and neither their taxonomy nor the ecology and behaviour of most species have been studied in detail. 
Treeshrews (order Scandentia, family Tupaiidae) belong to another important group of small mammals at the study site (here Tupaia glis). They have basically diversified on the ground. Also some local squirrels (family Sciruidae), e.g. Low's squirrel (Sundasciurus lowii), the Shrew-faced Ground squirrel (Rhinoscuirus laticaudatus) or the Plantain squirrel (Callosciurus notatus) predominately use lower forest strata to forage during the day (pers. obs.).

For this study, a mark and recapture programme of small mammals $(<250 \mathrm{~g})$ was conducted at a lowland rainforest reserve at the West coast of Peninsular Malaysia. The study was aimed to identifying the small mammal species at the study site. General abundances, biomasses, species-specific sex ratios, and diversity indices were addressed. The study site hosted two major vegetation types, i.e. lowland Dipterocarp forest and temporal waterlogged alluvial freshwater swamp vegetation [20], mainly occupied by e.g. rattans, Salacca spp. and Elaidoxa conferta. It was assumed that forest areas with a similar vegetation type would also host a similar small mammal community composition, i.e. that some species might prefer either one habitat.

\section{MATERIALS AND METHODS Study Site}

Trapping was conducted at a primary forest site within the Virgin Jungle Reserve (VJR) of the Segari Melintang Forest Reserve (SMFR, compartments 62 and $631 \mathrm{~A}$ ) in Manjung District, Perak, Peninsular Malaysia $\left(4^{\circ} 18^{\prime} \mathrm{N}, 100^{\circ} 34^{\prime} \mathrm{E}\right)$ (Figure 1).

The whole SMFR has a size of 2720 ha and contains 408 ha of strictly protected VJR. The rest is Permanent Forest Reserve (PFR) with areas that were selectively logged during the 1960's. No obvious differences between the PFR and VJR in vegetation structure and canopy density are visible as the vegetation in formerly logged areas has mainly recovered. The forest reserve is located near rural areas and prone to human disturbance at medium levels, especially at its edges. Occasional illegal logging of timber woods, collecting rattans and Bertam (Calamoideae), or poaching mammals (mainly Sus scrofa) and birds (pers. obs.) can be observed.

To the west, the study site is bordered by plantation land (oil palm Elaeis guineensis), to the south and east by rural areas, and to the north by plantations and poultry farms. It is crossed by some small, seasonal streams.

The study site is flat to undulating with extending elevation from sea level to app. $150 \mathrm{~m}$ above sea level.
The dominant vegetation types are lowland Dipterocarp forest and freshwater alluvial swamp forests. The maximum height of the closed canopy is about $40 \mathrm{~m}$ [20].

The climate of the study area is characterized by the northeast monsoon with highest precipitation from October to December (209 mm to $251 \mathrm{~mm}$ ). A short dry season typically lasts from June to July (84 $\mathrm{mm}$ to $90 \mathrm{~mm})$. Annual average rainfall in the study area is 1,881 mm (1911-1975). The annual average temperature is $26.8^{\circ} \mathrm{C}$ (1961-1990) with minimum and maximum annual averages of $22.6^{\circ} \mathrm{C}$ and $31.6^{\circ} \mathrm{C}$ respectively (1931-1975) (weather station Sitiawan $4^{\circ} 22^{\prime} \mathrm{N}$ $100^{\circ} 70^{\prime} \mathrm{E}, 7 \mathrm{~m}$ above sea level).

\section{Trapping plots}

Four 1 ha-sized $(100 \mathrm{~m} \times 100 \mathrm{~m})$ trapping plots were termed A, B, C and D and plot centres were located at least $150 \mathrm{~m}$ apart from each other. All plots lied near to the forest edge $(0-50 \mathrm{~m})$ (Figure 1) and were equally affected by human influences.

Plot A was located at the very forest edge and dominated by Dipterocarps and firm, undrained soils. It was directly flanked by oil palm plantations from one side, a small tar road that separated the forest from plantation from the second site, and the other two sides were surrounded by primary forest vegetation. Plot B and C were located in a freshwater alluvial swamp forest with a high proportion of rattans, Salacca spp. (both Calamoideae) and Elaiadoxa conferta that dominated the vegetation. The soils of major parts of both plots were seasonally waterlogged (except for the dry season). Both plots centres (B and C) were more than $60 \mathrm{~m}$ away from that road and oil palm plantation. Plot D was located at a slope. Its vegetation was dominated by Dipterocarps and Bertam (Eugeissonia tristis) and it resembled Plot A in its main vegetation, except for a higher abundance of Bertam. Its plot centre was around $100 \mathrm{~m}$ away from the forest edge and surrounded by forest from all sides.

\section{Trapping programme}

Trapping was conducted for forty days between July and August 2010. In each plot 100 handmade standard wire mesh traps (trap size $\mathrm{H} \times \mathrm{x}$ x D: $16 \mathrm{x}$ $16 \times 50 \mathrm{~cm}$, mesh size: $10 \times 10 \mathrm{~mm}$ ) were set. They were placed along winding trapping trails that followed vegetational gradients in order to be least invasive, and were equally spaced throughout the 1 ha area of the plot. Traps were placed on three different height levels i.e. on the ground, at c. $0.5 \mathrm{~m}$ on lianas and fallen tree 


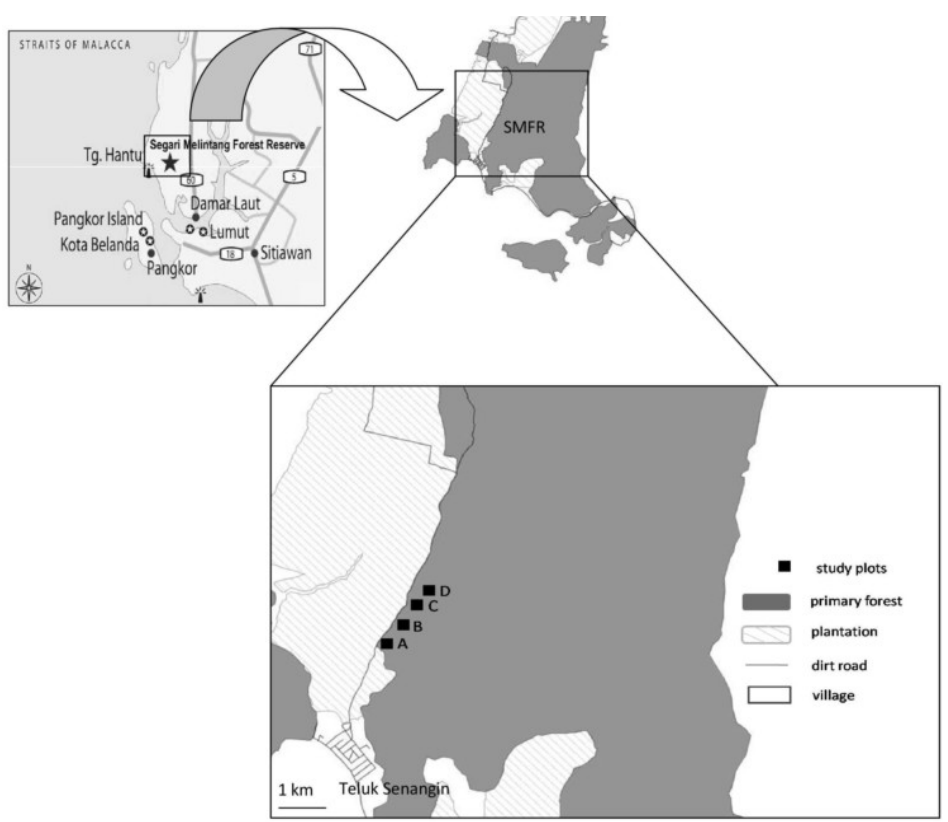

Figure 1. Location of the Segari Melintang Forest Reserve, Perak, Peninsular Malaysia (above). Location of the four $100 \mathrm{~m} \times 100 \mathrm{~m}$ study plots (A, B, C and D) within the SMFR near the village of Teluk Senangin (below).

trunks and c. 3-5 m heights up in the trees with equal distribution (app. 33 traps on each height level). Trapping was conducted for 10 consecutive days in each plot. The traps were baited with a banana in the late afternoon (05:00 p.m. - 07:30 p.m.). They were left open during the night and checked the following morning beginning at 9:00 a.m. Survey walks ended latest at 13:30 a.m. Species identification and nomenclature follows that of Francis [32].

\section{Animal handling}

Newly captured animals were transferred into a dark cloth bag where they were handled according to a standardized handling protocol without anesthesia. At first capture the following parameters of each individual were recorded: species, gender, age (estimated by size, and sexual maturity i.e. visible testes or nipples), weight (Wt), head-body-length from nose tip to anus in stretched position (HB), tail-length from anus to tail-tip (T), and hindfoot length (HF). Each was marked with a metal ear tag with a unique identification number (Nationalband Tag Co.). Handling in each took less than $5 \mathrm{~min}$ and then the animal was immediately released at the site. Individuals that were recaptured were identified by ear tag number and released from the traps immediately.

\section{Statistics}

Statistical tests (Chi Square test and Bray-Curtis dissimilarities) were calculated using $\mathrm{R}$ (version 2.14.2).

\section{Alpha-diversity}

The Shannon-Wiener Diversity Index $\left(\mathrm{H}^{\prime}\right)$ is a statistical index assessing $\alpha$-diversity in an area by considering species richness as well as the evenness of species distribution. Highest index values $\left(\mathrm{H}_{\max }\right)$ are reached if the distribution of individuals amongst the existing species in one area is even. $H^{\prime}$ is calculated by the following formula:

$$
H^{\prime}=-S \text { pi } \ln (p i) \text {; }
$$

with pi: proportion of the total number of species from the $\mathrm{i}^{\text {th }}$ species; $\mathrm{S}$ : species richness (total number of species in the community).

The maximum Shannon-Wiener Index was:

$H_{\max }=\ln (S)$.

The Evenness (E) that measures the equality or distribution of individuals amongst the species is calculated by:

$$
E=H^{\prime} / \ln (S) \text {. }
$$

\section{Beta-diversity}

The Bray-Curtis Index (B) compares species diversity between different sampling areas. B can reach levels between 0 and 1 , where 0 indicates that the species composition of two sampling areas are identical, thus showing the highest similarity. A value of 1 indicates the lowest possible similarity between two study plots. The Bray-Curtis Index is calculated by the formula: 


\section{$B=\Sigma\left[\left(X_{i-Y i}\right) /\left(X_{i}+Y_{i}\right)\right] ;$}

with $\mathrm{X}, \mathrm{Y}$ : compared areas; $\mathrm{Xi}$ and $\mathrm{Yi}$ : number of individuals per species of the compared areas.

\section{Mean abundances}

Each plot was trapped for ten consecutive days. As all captured individuals at the study site were tagged with metal ear-tags for permanent identification and all individuals were immediately released back into the population, the recapture rate of each individual could be noted. Here, "mean abundance" refers to the total number of different individuals per species caught in all plots divided by four, i.e. number of individuals per hectare (ind. ha ${ }^{-1}$ ).

\section{Sex ratios}

Sex ratios of all adult individuals were calculated. Adults were identified by weight, body lengths and signs of sexual activity, i.e. visible testes or nipple status (e.g. swollen, lactating) or palpable pregnancy. Some handled individuals escaped after ear tag application and before sex determination and were not recaptured again, thus not all animals could be sexed.

\section{RESULTS AND DISCUSSION}

\section{Capture summary}

A total of 14 species ( 9 genera) of small mammals were captured during 4000 trap nights (Table 1). In total 249 different individuals could be caught (Table 2). Mean trapping success was $13.7 \%$. Tupaia glis was the species caught most frequently $(\mathrm{N}=103)$, resulting in $39 \%$ of all captured animals.
Callosciurus notatus and Lenothrix canus were the second and third most common species, with 41 $(15.5 \%)$ and $40(15.1 \%)$ individuals, respectively. Spiny rats from the genus Maxomys, $M$. rajah $(\mathrm{N}=18,6.8 \%)$ and $M$. whiteheadi $(\mathrm{N}=14,5.3 \%)$ were ranked in fourth and fifth position. Species with the least number of catches belonged to the genus Niviventer, Sundamys, and Rattus (Table 2).

\section{Biomass}

Body measurements and mean biomasses of each species are listed in Table 4.

\section{Mean abundances}

Mean abundance of Tupaia glis was 26.3 individuals per hectare, accounting for approximately one third of all captured small mammals in Plot A, C, and D, and two thirds in Plot B (Table 2). Callosciurus notatus (10.3 ind. $\mathrm{ha}^{-1}$ ) was the second most dominant species in Plot A, with a quarter of all individuals represented there, but it was less dominant in the other plots. Lenothrix canus (mean abundance 10.0 ind. ha ${ }^{-1}$ ) was the second most abundant species in Plot C, accounting for $15 \%$ of all trapped individuals. In fourth and fifth place were $M$. rajah (4.5 ind. $\mathrm{ha}^{-1}$ ) and $M$. whiteheadi (3.5 ind ha ${ }^{-1}$ ).

\section{Tupaia glis}

In literature, 2-5 individuals of $T$. glis per hectare were reported in a Dipterocarp forest of the Malay Peninsula [15]. In this study however, a remarkably higher mean abundance of 26 animals per hectare was

Table 1. Species list of trapped small mammal species at the study site.

\begin{tabular}{|c|c|c|c|}
\hline Family & Scientific name & Description & English Name \\
\hline Tupaiidae & Tupsia glis & Diard 1920 & Common Treeshrew \\
\hline \multirow[t]{3}{*}{ Sciuridae } & Callosciurus notatus & Boddaert 1785 & Plantain Squirrel \\
\hline & Sundssciurus lowii & Thomas 1892 & Low's Squirrel \\
\hline & Callosciurus prevostii & Desmarest 1824 & Prevost's Squirrel \\
\hline \multirow[t]{10}{*}{ Muridae } & Lenothrix canus & Miller 1903 & Grey Tree Rat \\
\hline & Leopoldenays sabunus & Thomas 1887 & Long-tailed Giant Rat \\
\hline & Maxomys rajub & Thomas 1894 & Rajah Spiny Rat \\
\hline & Maxonys whiteherdi & Thomas 1894 & Whitehead's Spiny Rat \\
\hline & Mexongys surifer & Miller 1900 & Red Spiny Rat \\
\hline & Niviventer cremoriventer & Miller 1900 & Dark-tailed Tree Rat \\
\hline & Niviventer fulvescens & Gray 1847 & Chestnut White-bellied Rat \\
\hline & Rattus annendalei & Bonhote 1903 & Annandale's Rat \\
\hline & Rattus tiomsnicus & Miller 1900 & Malayan Field Rat \\
\hline & Sundangys muelleri & Jentink 1879 & Müller's Giant Sunda Rat \\
\hline
\end{tabular}


found. Tupaia glis lives in monogamous relationships, and pairs vigorously defend their territory [15]. The breeding season of $T$. glis on the Malaysian Peninsular has been shown to peak between February and June, and offspring grows to sexual maturity within seven months [15]. During this time, they still live within the parental territory. From August to November T. glis appears to be sexual inactive [21].

This study was conducted between July and August and might have fallen within the time frame when subadults still share the parental territories but already roam around and cross borders to adjacent territories to find mates. This could lead to a higher number of individuals compared to seasons when there is less roaming activity. However, taking into account that $T$. glis has an average litter size of only two [15] and only one third of all sexed individuals in this study were still subadults, this alone could not explain the high abundance of this species at the study site. The proximity of the study plots to vast oil palm plantation lands that serve as additional foraging ground may help in supporting a bigger population. Other particular effects of micro-habitat sites, e.g. high food availability before and during the study period, or a lack of diurnal predators could also positively influence abundances.

\section{Callosciurus notatus}

The mean abundance of $C$. notatus was described with 5.1 individuals per hectare in a lowland Dipterocarp forest of the Malay Peninsula [22], which is half of the individual number that was found in this study. Sampling methods and habitat structure between both studies differed slightly. Saiful and Nordin conducted a mark and recapture study at higher elevations $(240 \mathrm{~m}$ a.s.l.) and used fewer traps (30) which were shifted more frequently (5 days). This different trapping set-up might have led to a lower encounter probability of traps that resulted in lower observed individual numbers (i.e. observed mean abundance). Callosciurus notatus is widely found in areas of human disturbance, such as cultivated land, secondary forests, and parks and rarely in undisturbed primary forest habitats [2324]. Again, the proximity to vast plantation lands, which offer additional foraging opportunities for this

Table 2. Absolute and relative abundances, diversity and relative trapping success of small mammal species in the study plots A - D.

\begin{tabular}{|c|c|c|c|c|c|c|}
\hline \multirow[b]{2}{*}{ Species } & \multicolumn{4}{|c|}{ Plot } & \multirow{2}{*}{$\begin{array}{c}\text { number } \\
\text { of individuals }\end{array}$} & \multirow{2}{*}{$\begin{array}{l}\text { relative proportion } \\
\qquad(\mathrm{N}=249)\end{array}$} \\
\hline & A & B & C & $\mathrm{D}$ & & \\
\hline Tupais glis & 22 & 31 & 22 & 28 & 103 & $38.9 \%$ \\
\hline Callosciurus notatus & 16 & 9 & 11 & 5 & 41 & $15.5 \%$ \\
\hline Lenothrix canus & 7 & 5 & 16 & 12 & 40 & $15.1 \%$ \\
\hline Maxomys rajah & 3 & 1 & 3 & 11 & 18 & $6.8 \%$ \\
\hline Maxomys whiteheadi & 0 & 1 & 4 & 9 & 14 & $5.3 \%$ \\
\hline Rattus annandalei & 4 & 4 & 0 & 0 & 8 & $3.0 \%$ \\
\hline Leopoldamys sabanus & 3 & 1 & 1 & 3 & 8 & $3.0 \%$ \\
\hline Maxomys surifer & 4 & 0 & 0 & 1 & 5 & $1.9 \%$ \\
\hline Sundasciurus lowii & 1 & 0 & 1 & 1 & 3 & $1.1 \%$ \\
\hline Niviventer cremoriventer & 2 & 0 & 1 & 0 & 3 & $1.1 \%$ \\
\hline Callosciurus prevostii & 0 & 1 & 1 & 0 & 2 & $0.8 \%$ \\
\hline Niviventer fulvescens & 0 & 0 & 2 & 0 & 2 & $0.8 \%$ \\
\hline Rattus tiomanicus & 1 & 0 & 0 & 0 & 1 & $0.4 \%$ \\
\hline Sundamys muelleri & 1 & 0 & 0 & 0 & 1 & $0.4 \%$ \\
\hline Number of individuals & 64 & 52 & 61 & 70 & 249 & $100 \%$ \\
\hline Species richness $(S)$ & 11 & 8 & 10 & 8 & 14 & \\
\hline Shannon-Wiener index $\left(\mathrm{H}^{\prime}\right)$ & 1.89 & 1.34 & 1.71 & 1.67 & & \\
\hline Evenness (E) & 0.72 & 0.51 & 0.65 & 0.63 & & \\
\hline Total trap effort & 1000 & 1000 & 1000 & 1000 & 4000 & \\
\hline Trap success & $13.3 \%$ & $14.0 \%$ & $12.5 \%$ & $15.1 \%$ & mesn $13.7 \%$ & \\
\hline
\end{tabular}


Table 3. Sex ratio of adult small mammals (male : female).

\begin{tabular}{|c|c|c|c|c|c|c|}
\hline I. $\mathrm{glis}$ & C. notater & $M_{\mathrm{raj} a h}$ & L. caness & $M$ wbitteheadi & L. sabanes & R. annandalei \\
\hline$(N=61)$ & $(\mathrm{N}=33)$ & $(\mathrm{N}=11)$ & $(\mathrm{N}=22)$ & $(N=8)$ & $(N=6)$ & $(N=6)$ \\
\hline $103: 1$ & $0.94: 1$ & $120: 1$ & $4.50: 1$ & $7.00: 1$ & $200: 1$ & $5,00: 1$ \\
\hline
\end{tabular}

opportunistic species, might be responsible for its high abundance at the study site.

\section{Lenothrix canus}

Only very little is described about $L$. canus in the literature, and hardly anything about its general abundance in Malaysian primary habitats can be found. During a two years life-trapping study on small mammal communities on Borneo only two individuals of $L$. canus were trapped in a primary forest. Here, a total of 1218 individuals of other species were captured. [25]. No further note on this species could be found in the available literature. In this study, L. canus measured for $15 \%$ of all captured small mammals and was the third most abundant species at the study site. Its high abundance may, again, be a feature of the study site. However, as far as the authors are aware of, this species is not addressed in any paper on small mammal communities of the Peninsular. Therefore, no comparison to other forest areas in the region can be drawn.

\section{Leopoldamys sabanus}

In a study at the lowland Dipterocarp forest of $\mathrm{Pa}$ soh (West-Malaysia) L. sabanus was found to be the most abundant species [13]. There, capture rates for $L$. sabanus were four times higher than for $T$. glis, which was the second most abundant species. In this study, L. sabanus was represented by only eight individuals ( 2 ind. ha $^{-1}, 3 \%$ of overall captures). The differences in abundances to this study site might be due to effects of the habitat structure, as the dominant vegetation at the study site of Pasoh forest was described as Meranti and hill Dipterocarp forest.

\section{Maxomys spp.}

A long-term study on population dynamics of Maxomys rajah and M. whiteheadi by [26] at a lowland Dipterocarp forest in Sarawak (Lambir Hill National Park) revealed the high fluctuations in abundance levels. Individual numbers varied from app. 0-9 individuals per 1.32 hectares in both species during several trapping events from 1997 until 2006. These findings are well within the range of our current results. No references on this genus could be found in the literature for the Peninsular.

\section{Sex ratios}

Sex ratios of the seven most frequently captured species is shown in Table 3. Sex ratios of Tupaia glis ( $\mathrm{N}=61), C$. notatus $(\mathrm{N}=33)$, M. rajah $(\mathrm{N}=11)$ and L. sabanus $(\mathrm{N}=6)$ were nearly 1:1 (male: female). High discrepancies amongst the sexes could be found in $R$. annandalei $(5: 1, \mathrm{~N}=6)$, L canus $(4.5: 1, \mathrm{~N}=22)$, and $M$. whiteheadi (7:1, N=8).

The asymmetric sex-ratios of the described Muridae species might be due to a sexed-biased aversion to traps. Females, in general, seem to be more trap-shy than males [31]. On the other hand, it could also be a stochastical effect due to the short study period and low sampling number.

Their high capture rates of $T$. glis allowed to take a closer look at this species: subadults were defined by a weight less than $150 \mathrm{~g}$ [27]. Sex-ratio of all sexed animals including subadults was 1:1.3 (male: female, $\mathrm{N}=89$ ) and 1:1 amongst adults $(\mathrm{N}=61)$. Tupaia glis is reported to be monogamous or polygynous [27]. The union between males and females seems permanent as revealed by scent marking between the pair and sharing of the same territory [28-29]. They form small temporary family groups $[15,28]$ and the male and female of the primary pair heavily defend their territory against co-specific intruders. However, when foraging, they are mostly observed solitary and intersexual encounters are much more frequent than intrasexual encounters. Home ranges of adult residents of the same sex do only little overlap, but pairs or harems do share almost entirely the same home range [21].

\section{Diversity indices Alpha-diversity}

Shannon-Wiener Diversity Indices (H') in all plots were at medium levels compared to $\mathrm{H}_{\max }$ (2.64). Highest $\mathrm{H}^{\prime}$-values were assessed in Plot A (1.89, $\mathrm{E}=0.72$ ) and in Plot $\mathrm{C}$ (1.71, $\mathrm{E}=0.65)$ (Table 2).

\section{Beta-diversity}

Species composition amongst the four study plots differed significantly $\left(\chi^{2}=79.10\right.$, d.f. $\left.39, \mathrm{p}<0.01\right)$. BrayCurtis values (B) varied between 0.26-0.37. The highest values were achieved for comparison of plot $A$ with $D$ (0.37), and B with $\mathrm{D}(0.34)$. Those were the plots least 
Table 4. Mean body measurements and mean biomass per hectare of small mammals at the study site.

\begin{tabular}{|c|c|c|c|c|c|}
\hline Species & Wt (g) & HB (mm) & $T(\mathrm{~mm})$ & $\mathrm{HF}(\mathrm{mm})$ & $\mathrm{g} \mathrm{ha}^{-2}$ \\
\hline \multirow[t]{2}{*}{ Tupaia glis } & $158( \pm 27)$ & $160( \pm 16)$ & $166(=10)$ & $43( \pm 2)$ & $4,068.5$ \\
\hline & $\mathrm{N}=92$ & $\mathrm{~N}=86$ & $\mathrm{~N}=92$ & $\mathrm{~N}=92$ & \\
\hline \multirow[t]{2}{*}{ Callosciurus notatus } & $252( \pm 44)$ & $175( \pm 18)$ & $179( \pm 27)$ & $43( \pm 5)$ & $2,583.0$ \\
\hline & $\mathrm{N}=38$ & $\mathrm{~N}=30$ & $\mathrm{~N}=35$ & $\mathrm{~N}=35$ & \\
\hline \multirow[t]{2}{*}{ Callosciurus prevostii } & $420( \pm 42)$ & $230(-)$ & $255( \pm 7)$ & $55( \pm 0)$ & 210.0 \\
\hline & $N=2$ & $\mathrm{~N}=1$ & $\mathrm{~N}=2$ & $\mathrm{~N}=2$ & \\
\hline \multirow[t]{2}{*}{ Sundasciurus lowii } & $67( \pm 6)$ & $93( \pm 18)$ & $85( \pm 49)$ & $30( \pm 0)$ & 50.3 \\
\hline & $\mathrm{N}=3$ & $\mathrm{~N}=2$ & $\mathrm{~N}=2$ & $\mathrm{~N}=2$ & \\
\hline \multirow[t]{2}{*}{ Maxomys surifer } & $135( \pm 64)$ & $172( \pm 10)$ & $203( \pm 23)$ & $36( \pm 8)$ & 168.8 \\
\hline & $\mathrm{N}=4$ & $\mathrm{~N}=3$ & $\mathrm{~N}=4$ & $\mathrm{~N}=4$ & \\
\hline \multirow[t]{2}{*}{ Maxomys rajah } & $118( \pm 55)$ & $141( \pm 32)$ & $158( \pm 58)$ & $35( \pm 8)$ & 531.0 \\
\hline & $\mathrm{N}=17$ & $N=16$ & $N=16$ & $N=16$ & \\
\hline \multirow[t]{2}{*}{ Maxomys whiteheadi } & $47( \pm 18)$ & $106( \pm 10)$ & $99( \pm 7)$ & $25( \pm 0)$ & 164.5 \\
\hline & $\mathrm{N}=10$ & $\mathrm{~N}=10$ & $\mathrm{~N}=10$ & $\mathrm{~N}=10$ & \\
\hline \multirow[t]{2}{*}{ Lenothrix canus } & $132( \pm 56)$ & $152( \pm 32)$ & $210( \pm 37)$ & $32( \pm 5)$ & 1,320 \\
\hline & $\mathrm{N}=34$ & $\mathrm{~N}=30$ & $\mathrm{~N}=30$ & $N=30$ & \\
\hline \multirow[t]{2}{*}{ Rattus tiomanicus } & 40 & - & 160 & 30 & 10.0 \\
\hline & $N=1$ & - & $N=1$ & $\mathrm{~N}=1$ & \\
\hline \multirow[t]{2}{*}{ Rattus annandalei } & $185( \pm 18)$ & $177( \pm 24)$ & $220( \pm 32)$ & $39( \pm 2)$ & 370.0 \\
\hline & $N=6$ & $N=6$ & $N=6$ & $N=6$ & \\
\hline \multirow[t]{2}{*}{ Sundamys muelleri } & 200 & - & 240 & 40 & 50.0 \\
\hline & $\mathrm{N}=1$ & - & $\mathrm{N}=1$ & $\mathrm{~N}=1$ & \\
\hline \multirow[t]{2}{*}{ Niviventer cremoriventer } & $170(=14)$ & $175( \pm 28)$ & $220( \pm 14)$ & $34( \pm 2)$ & 127.5 \\
\hline & $\mathrm{N}=2$ & $\mathrm{~N}=2$ & $\mathrm{~N}=2$ & $\mathrm{~N}=2$ & \\
\hline \multirow[t]{2}{*}{ Niviventer fulvescens } & $125( \pm 7)$ & $130( \pm 0)$ & $240( \pm 42)$ & $39(=1)$ & 62.5 \\
\hline & $\mathrm{N}=2$ & $\mathrm{~N}=1$ & $\mathrm{~N}=2$ & $\mathrm{~N}=2$ & \\
\hline \multirow[t]{2}{*}{ Leopoldamys sabanus } & $265( \pm 58)$ & $194( \pm 29)$ & $328( \pm 57)$ & $42( \pm 8)$ & 530.0 \\
\hline & $N=8$ & $\mathrm{~N}=6$ & $\mathrm{~N}=7$ & $\mathrm{~N}=7$ & \\
\hline
\end{tabular}

similar in their small mammal species composition. The lowest values were achieved for the plots $C \& D$ (0.26), and $A \& C(0.28)$, respectively. Those plots resembled one another to the most in small mammal species composition (Figure 2).

Here, it is noteworthy that the plots that resemble one another the most in their dominant vegetation type $(A \& D$ vs. $B \& C)$ do not host the most similar small mammal species assemblage. On the contrary, plots A and D (both dominated by Dipterocarps and dry, undrained soils) were found to be least similar.

Shannon-Wiener indices of all plots ranged from mediocre levels ( $\mathrm{H}^{\prime}$ 1.34-1.89, $\mathrm{H}_{\max }$ 2.64). Although lying in considerable proximity to each other, there were significant differences in species composition in the different study plots as revealed by Chi-square test. Plot A hosted the highest species richness and $\alpha$-diversity, possibly because more individuals from species adapted to the oil-palm plantations (e.g. C. notatus, $R$. tiomanicus, and $R$. annandalei) [23-24, 30] could be trapped here. This plot is located at the outermost edge of the forest and joins oil palm plantations directly from one side. Thus, plot A might host both primary forest dwellers as well as species adapted to foraging in plantations or secondary forests $[24,30]$. Except of plot A, all the other plots are separated from the plantation by a small tar road that is frequently used by oil palm trucks and cars of nearby residents. The road might act as a crossing barrier for some small mammal species.

Bray-Curtis values ranged from 0.26 to 0.37 , which indicates that all plot pairs are quite similar in their species composition as the values are nearer to zero (very similar) than to one (very dissimilar). Plots $\mathrm{C}$ and $\mathrm{D}$ are the most similar and plots $\mathrm{A}$ and $\mathrm{D}$ the least similar in their small mammal community. Plots $C$ and $\mathrm{D}$ lie in close proximity to one another, but their main 


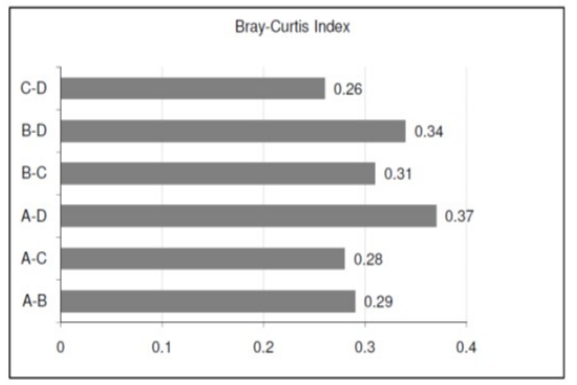

Figure 2. Comparison of Beta-diversity amongst the study plots (A-D) assessed by Bray-Curtis indices.

vegetation structure differs. Plot $\mathrm{C}$ is mainly composed of alluvial fresh water swamp vegetation with temporarily flooded areas, while plot D lies at a dry hill site dominated by Dipterocarps and Bertam. Plots A and D were situated furthest away from one another. While plot $A$ is situated at the very forest margin, plot $D$ lies farthest away from the forest edge.

Both plots were quite similar in their main vegetation structure, dominated by Dipterocarps and dry soils on gentle slopes. Therefore, there seems to be no direct link between dominant vegetation structure (Dipterocarps vs. seasonal swamp) to the community composition of small mammals. Other factors, such as the distance of the plots to the forest edge, the proximity to oil palm plantations or the existence of potential crossing barriers to the plantation (e.g. road), might lead to differences in the community structure. as Those edge effects might increase the abundance of opportunistic species at forest-plantation borders. Nevertheless, a longer-termed study with higher sampling numbers should be conducted in order to address this aspect in further detail.

Here, it was shown that sampling plots, which were in close proximity to one another, hosted a significantly different small mammal species composition. Although, the plots differed in their dominant vegetation type no obvious link between species assemblage in Dipterocarp forest plots or seasonally waterlogged alluvial fresh water swamp plots could be established. All plots were considerably close to vast oil palm plantation lands that offer additional foraging opportunities, thus allowing opportunistic species like Tupaia glis or Callosciurus notatus to thrive in high abundances.

Muridae species are nocturnal and rather cryptic and thus could only rarely be observed foraging in the wild. Many of the local rat species are still only very little studied or addressed in literature. Here, all Muridae species showed male-biased sex ratios, either indicating that females were more trap shy than males [31] or that the population is skewed towards a higher number of males. Lenothrix canus was the third most abundant species in the area. Still, this species seems to be least studied amongst all local Muridae species because hardly anything on the biology of this species can be found in published literature. This offers opportunity for future studies of this species, especially as it was found to be potentially involved in pollination processes (Frank Wiens pers. comm.)

\section{CONCLUSIONS}

This study was aimed at giving a general insight in a small mammal community at a local primary forest reserve. As the study period was quite restricted, it showed only a snap shot of this very diverse and dynamic part of the ecosystem that is constantly changing. Still more data is needed to assess species abundance changes during breeding seasons or due to climate factors that might influence fruit availability; and species dynamics affected by immigration, emigration and birth-, death rates. An advanced trapping study, which uses a different marking technique and addresses those aspects, is currently in progress. Nevertheless, this paper already gave valuable insights in a rain forest guild that is highly diverse and of outstanding value to the forest ecosystem. Unfortunately, they are also under constant threat due to deforestation and habitat loss in the region.

The original size of the SMFR had been reduced by over 50\% (from originally 4566 ha in the 1960's). During the last few decades the ongoing forest fragmentation and encroachment has been putting additional pressure on the survival of small mammal populations. This is particularly alarming as many aspects of the biology of most species (especially Muriade) mentioned herein have not been studied yet.

Small mammals play a crucial role for the biotic processes (like seed dispersal) of the rain forest ecosystem. Studying their behaviour and biology is vital if one wants to fully understand the jigsaw of rain forest dynamics. Only by understanding how the different components of this jigsaw work together we will be able to act towards conservation and preservation of this highly vulnerable ecosystem.

\section{ACKNOWLEDGMENT}

We thank the following persons who helped with practical aspects: Mat Nor Bin Mohamad Akhir, Marion Renner and Damaris Ehmann. This study was supported by RU USM-Postgraduate Research Grant 
(1001/P BIOLOGI/843098) and Universiti Sains Malaysia Research University Grant (1001/P BIOLOGI/811131). We acknowledge the Perak State Forestry Department for issuing respective permits.

\section{REFERENCES}

1. Khan MM (1992) Mamalia Semenanjung Malaysia. Kuala Lumpur: Jabatan Perhilitan.

2. Carthew SM, Goldingay RL (1997) Non-flying mammals as pollinators. Trends Ecol Evolut. 12(3): 104-108.

3. Johnson SD, Burgoyne PM, Harder LD, Dötterl S (2010) Mammal pollinators lured by the scent of a parasitic plant. Proc R Soc B. DOI:10.1098/rspb.2010.2175.

4. Wiens D, Rourke JP, Casper BB, Rickart EA, LaPine TR, Peterson CJ, Channing A (1983) Nonflying mammal pollination of Southern African proteas: a non-coevolved system. Sant Louis: Annals of the Missouri Botanical Garden. 70(1): 1-31.

5. Emmons LH (1991) Frugivory in treeshrews (Tupaia). Amer Nat. 138(3): 642-649.

6. Miura S, Yasuda M, Ratnam LC (2007) Who steals the fruit? Monitoring frugivory of mammals in a tropical rain forest. Mal Nat J. 50: 183-193.

7. Shanahan M, Compton SG (2003) Fig-eating by Bornean treeshrews (Tupaia spp.): evidence for a role as seed dispersers. Biotrop. 2(4a): 759-764.

8. van der Meer PJ, Kunne PLB, Brunsting AMH, Dibor LA, Jansen PA (2008) Evidence of scatter-hoarding in a tropical peat swamp forest in Malaysia. J Trop For Sc. 20(4): 340-343.

9. Yasuda M, Miura S, Ishii N, Okuda T, Nor AH (2005) Fallen fruits and terrestrial vertebrate frugivores: a case study in a lowland tropical rainforest in Peninsular Malaysia. In: Forget P-M, Lambert JE, Hulme PE, Vander Wall SB, eds. Seed Fate. Wallingford (UK): CAB International. 151-174.

10. Wilting A, Fischer F, Abu Bakar S, Linsenmair KE (2006). Clouded leopards, the secretive top-carnivore of SouthEast Asian rainforests: their distribution, status and conservation needs in Sabah, Malaysia. BMC Ecol. 6(16).

11. Wells K, Lakim, MB, Bernard H, Pfeiffer M (2004)a. Small mammals in the rainforest canopy: a neglected group of conservational concern? ASEAN Review of Biodiversity \& Environmental Conservation [http://www.arbec.com.my/smallmammals].

12. Akbar Z, Ariffin MKE (1997) A comparison of small mammals abundance between primary and disturbed lowland rainforest in Peninsular Malaysia. Mal Nat J. 50: 201206.

13. Kemper C, Bell DT (1985) Small mammals and habitat structure in lowland rain forest of Peninsular Malaysia. J
Trop Ecol. 1: 5-22.

14. Laidlaw RK (2000) Effect of habitat disturbance and protected areas on mammals of Peninsular Malaysia. Conserv Biol. 4(6): 1639-1648.

15. Langham NPE (1982) The ecology of the Common treeshrew, Tupaia glis in Peninsular Malaysia. J Zool. 197: 323-344.

16. Langham NPE (1983) Distribution and ecology of small mammals in three rain forest localities of Peninsular Malaysia with particular reference to Kedah Peak. Biotrop. 3: 199-206.

17. Syed-Arnez ASK, Mohd Zain SN (2006) A study on wild rats and their endo-parasite fauna from the Endau Rompin National Park, Johor. Mal. J Sci. 25(2): 19-39.

18. Meijaard E, Sheil D (2008) The persistence and conservation of Borneo's mammals in lowland rain forests managed for timber: observations and opportunities. Ecol Res. 23: 21-23.

19. Wells K, Pfeiffer M, Lakim MB, Linsenmair KE (2004)b Use of arboreal and terrestrial space by small mammal community in a tropical rain forest in Borneo, Malaysia. J Biogeo. 31: 641-654.

20. Wiens F, Zitzmann A (2003) Social structure in the solitary slow loris Nycticebus councang (Lorisidae). J Zool. 261: 35-46.

21. Kawamichi T, Kawamichi M (1982) Social system and independence of offspring in treeshrews. Primates. 23: 189205.

22. Saiful AA, Nordin M (1994) Diversity and density of diurnal squirrel in a primary hill dipterocarp forest, Malaysia. J Trop Ecol. 20: 45-49.

23. Tamura N, Yong HS (1993) Vocalizations in response to predators in three species of Malaysian Callosciurus (Sciruidae). J Mammal. 74: 703-714.

24. Constantine J (2006) Callosciurus notatus, Animal Diversity Web [http://animaldiversity.ummz.umich.edu/accounts/Callosciurus_notatus]

25. Wells K, Kalko EKV, Lakim MB, Pfeiffer M (2007) Effects of rain forest logging on species composition of small mammals in Southeast Asia. J Biogeo. 34: 1087-1099.

26. Nakagawa M, Miguchi H, Sato K, Sakai S, Nakashizuka T (2007) A preliminary study of two sympatric Maxomys rats in Sarawak, Malaysia: spacing patterns and population dynamics. Raff Bull Zool. 55(2): 381-387.

27. Kawamichi T, Kawamichi M (1979) Spatial organization and territory of treeshrews (Tupaia glis). Anim Behav. 27: 381-393.

28. Von Holst D (1994) Auswirkung sozialer Kontakte bei Säugetieren. Biol in uns Zeit. 24(4): 164-174.

29. Munshi-South J (2006) Asocial monogamy, extra-pair paternity, and dispersal in the large treeshrew (Tupaia tana). 
$\mathrm{PhD}$ thesis. University of Maryland, Faculty of the Graduate School.

30. Wood BJ (1984) A long-term study of Rattus tiomanicus populations in an oil palm plantation in Johore, Malaysia: study methods and population size without control. J App
Ecol. 21: 445-464.

31. Wolfe JL (1985) Population ecology of the Rice rat (Oryzomys palustris) in a coastal marsh. J Zool. 205: 235-244.

32. Francis, CM (2008) A field guide to the mammals of South-East Asia. Princeton University Press. 